\title{
Screening oat landraces for resistance to Blumeria graminis f. sp. avenae
}

\author{
Sylwia Okoń ${ }^{1}$ (D) Krzysztof Kowalczyk ${ }^{1}$ (D)
}

Received: 1 October 2019 / Accepted: 25 January 2020 / Published online: 17 February 2020

(C) The Author(s) 2020

\begin{abstract}
Landraces have considerable potential for use in increasing genetic diversity of cultivated crops. They present a unique source of specific traits for disease and pest resistance, nutritional quality and marginal environment tolerance. In this study we screened of 156 A. sativa and A. strigosa landraces originated from Poland, for resistance to powdery mildew disease, caused by Blumeria graminis f. sp. avenae. In general, the tested genotypes showed lower level of resistance than expected. Among A. sativa landraces five were resistant to single isolates, the rest of them showed intermediate or susceptible response to B. graminis f. sp. avenae isolates used in host-pathogen tests. One A. strigosa genotype was resistant to all tested isolates and could be valuable source of resistance against oat powdery mildew.
\end{abstract}

Keywords Oat $\cdot$ Powdery mildew $\cdot$ Landraces $\cdot$ Resistance

Diseases caused by fungal pathogen are one of the main factors reducing yield and grain quality in crops production. Among them the most important are rust diseases (leaf rust, brown rust, crown rust), powdery mildew, diseases caused by members of the genus Fusarium (Bentley et al. 2006; Kuzdraliński et al. 2017, 2018; Figueroa et al. 2018). One of the most important foliar diseases of oat is powdery mildew caused by Blumeria graminis DC. f. sp. avenae Em. Marchal. This disease appears every year and has been reported as a serious problem in many parts of the world (Roderick et al. 2000; Sebesta et al. 1991, Banyal et al. 2016, Xue et al. 2017). Limiting the losses caused by the occurrence of this pathogen is based on appropriate agrotechniques and introduction of resistant cultivars (Gacek 2000; Tratwal and Rosiak 2010). To date, ten genes conferring resistance to oat powdery mildew have been characterised, but based on reports from available literature only a few are high effective against existing Blumeria graminis DC. f. sp. avenae populations. (Okoń 2015; Okoń and Ociepa 2017). Resistance to powdery mildew is decreasing due to the emergence of new pathogen pathotypes by mutations and recombinations. Also using the

Krzysztof Kowalczyk

Krzysztof.Kow22@gmail.com

1 Institute of Plant Genetics, Breeding and Biotechnology, University of Life Sciences, Lublin, Poland same set of resistance genes in breeding programmes could result in the selection of pathotypes with the matching virulence genes, resulting in resistance breakdown (Czembor and Czembor 2001). Menardo et al. (2016) suggested that also hybridization between formae speciales is a mechanizm of adaptation to new crops introduced by agriculture. Because of these facts there is a need to search for novel and effective sources of resistance to powdery mildew in oat. A valuable source of genetic variation, and thus the source of resistance genes can be both wild species and landraces.

Landraces are dynamic, heterogeneous crops populations composed of numerous homozygous lines or individuals with various level of heterozygosity (Boczkowska and Onyśk 2016). Landraces envolved in response to natural selection for the local environment, mutations, migrations and genetic drift. Consequently they are well adapted to local conditions including biotic and abiotic stress factors (Frankel et al. 1995; Villa et al. 2005; Mohammadi et al. 2014; Pusadee et al. 2014). Several studies suggest that landraces may be a good source of new allelic diversity for breeding programs. They are valuable sources of quality traits (Pecetti et al. 2001; Moragues et al. 2006; Li et al. 2009; Teklu and Hammer 2009), agro-ecological adaptation (van Hintum and Elings 1991), abiotic stresses (Reynolds et al. 2006; Trethowan and Mujeeb-Kazi 2008) and resistance to pests and diseases (Saker et al. 2008; Li et al. 2009; Sánchez-Martín et al. 2011, 2012). 
Fig. 1 Geographic origin of graminis $\mathrm{f}$. $\mathrm{sp}$. avenae isolates

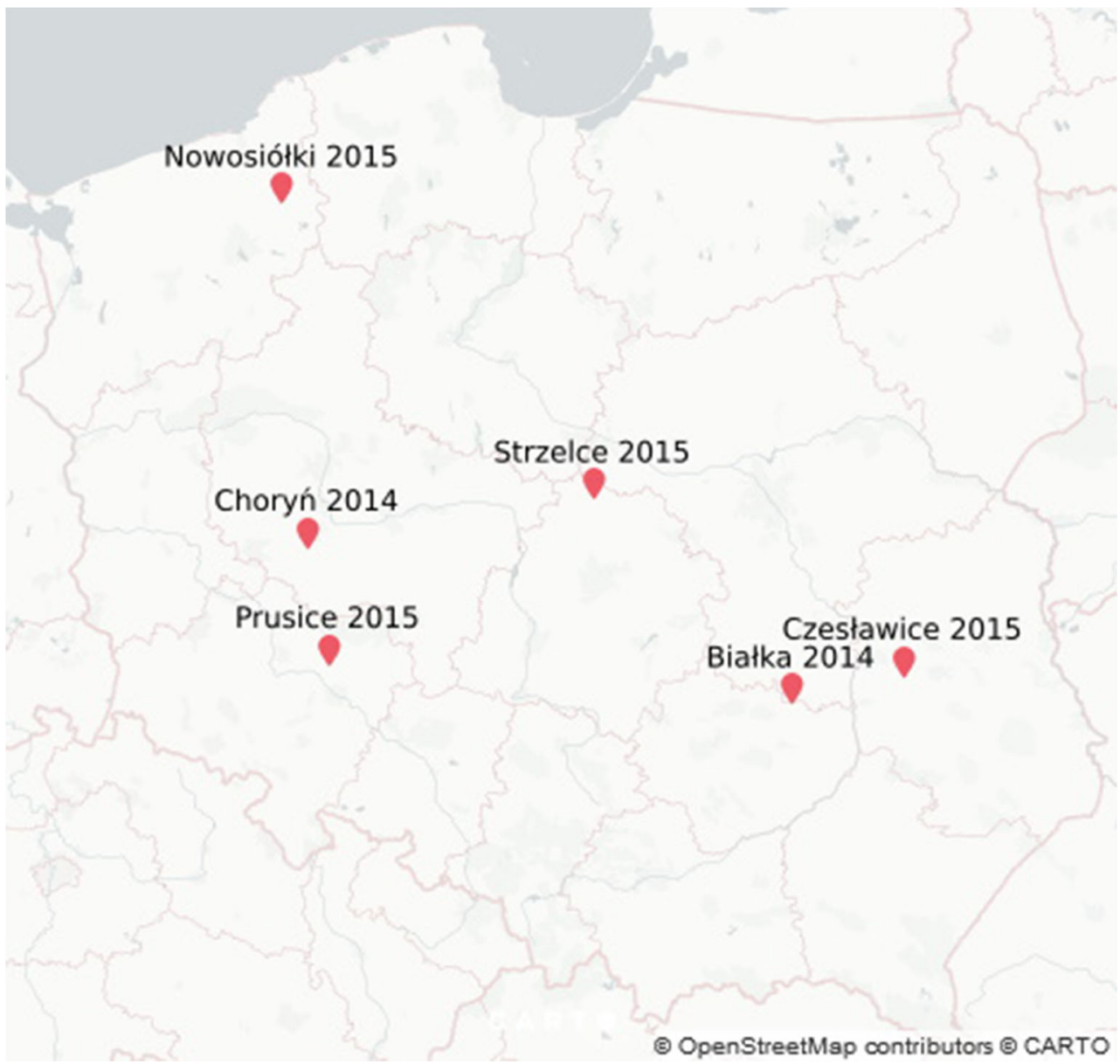

Bacause of this fact, the aim of presented study was screening a group of 156 oat landraces belonging to A. sativa and A. strigosa species for resistance to Blumeria graminis f. sp. avenae causing powdery mildew in oats.

All genotypes were received from two gene banks: The Plant Breeding and Acclimatization Institute (IHAR), Radzikow, Poland and Leibniz Institute of Plant Genetics and Crop Plant Research, Gatersleben, Germany.

Host-pathogen tests described by Okoń and Kowalczyk (2012) were used to determine resistance of the analyzed genotypes. Disease on the leaves was rated 10 days after inoculation according to 0-4 modified scale (Mains 1934). Many studies aimed at identifying new sources of disease resistance are based on tests with one highly virulent pathogen isolate (Sánchez-Martín et al. 2012; Herrmann and Mohler 2018). Okoń et al. (2018) underline that it is necessary to perform tests based on a diverse set of pathogen isolates in order to obtain reliable results on the effectiveness of disease resistance. Observations based on isolates sampled in one region or in one year may be insufficient to draw reliable conclusions. In

Table 1 Virulence of Blumeria graminis $\mathrm{f}$. sp. avenae isolates chosen for testing oat landraces

B. graminis f.sp. avenae Isolates Control lines and cultivars ${ }^{\mathrm{b}}$

\begin{tabular}{llllllll}
\hline Jumbo Pm1 & Cc3678 Pm2 & Mostyn Pm3 & Av1860 Pm4 & Am 27 Pm5 & Bruno Pm6 & APR122 Pm7 & Fuchs \\
\hline $\mathrm{I}$ & $\mathrm{R}$ & $\mathrm{I}$ & $\mathrm{R}$ & $\mathrm{R}$ & $\mathrm{S}$ & $\mathrm{I}$ & $\mathrm{S}$ \\
$\mathrm{R}$ & $\mathrm{R}$ & $\mathrm{S}$ & $\mathrm{R}$ & $\mathrm{R}$ & $\mathrm{S}$ & $\mathrm{R}$ & $\mathrm{S}$ \\
$\mathrm{S}$ & $\mathrm{R}$ & $\mathrm{S}$ & $\mathrm{R}$ & $\mathrm{R}$ & $\mathrm{S}$ & $\mathrm{R}$ & $\mathrm{S}$ \\
$\mathrm{S}$ & $\mathrm{R}$ & $\mathrm{S}$ & $\mathrm{R}$ & $\mathrm{R}$ & $\mathrm{S}$ & $\mathrm{S}$ & $\mathrm{S}$ \\
$\mathrm{S}$ & $\mathrm{R}$ & $\mathrm{S}$ & $\mathrm{R}$ & $\mathrm{R}$ & $\mathrm{S}$ & $\mathrm{I}$ & $\mathrm{S}$ \\
$\mathrm{I}$ & $\mathrm{I}$ & $\mathrm{S}$ & $\mathrm{R}$ & $\mathrm{R}$ & $\mathrm{S}$ & $\mathrm{R}$ & $\mathrm{S}$ \\
\hline
\end{tabular}

$R$ resistant, $I$ intermediate, and $S$ susceptible 


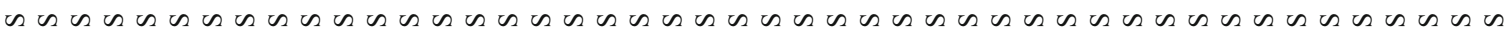

.

空

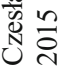

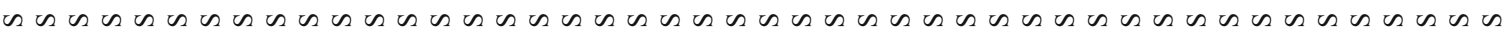

$\frac{\bar{y}}{0}$

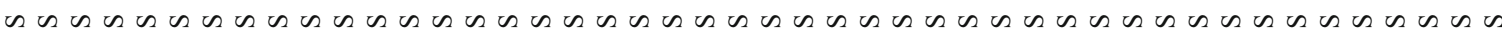
$\stackrel{n}{0}$

กิ

$\stackrel{8}{8}$

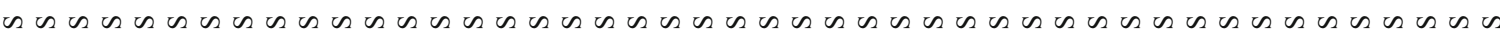

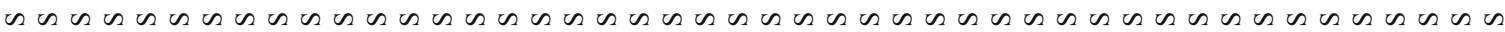
$\underset{0}{ \pm}$

ำ

苍苛

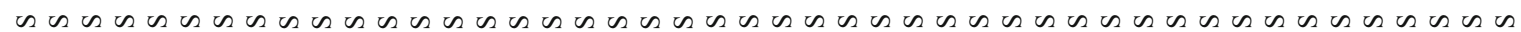

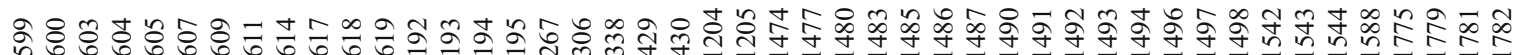

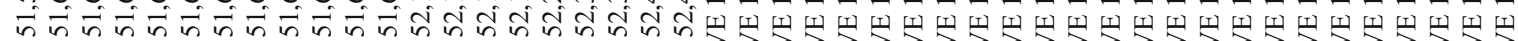

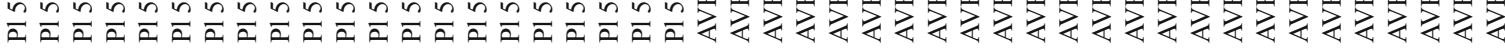

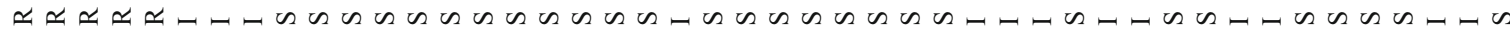
8

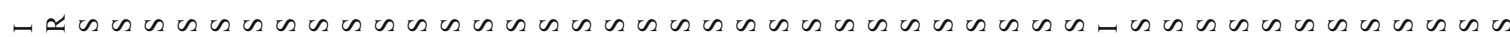
$\overline{\frac{1}{0}}$

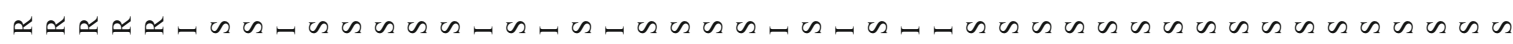
n

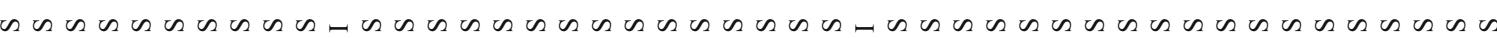

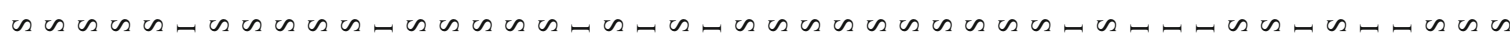
さ ㅇำ 


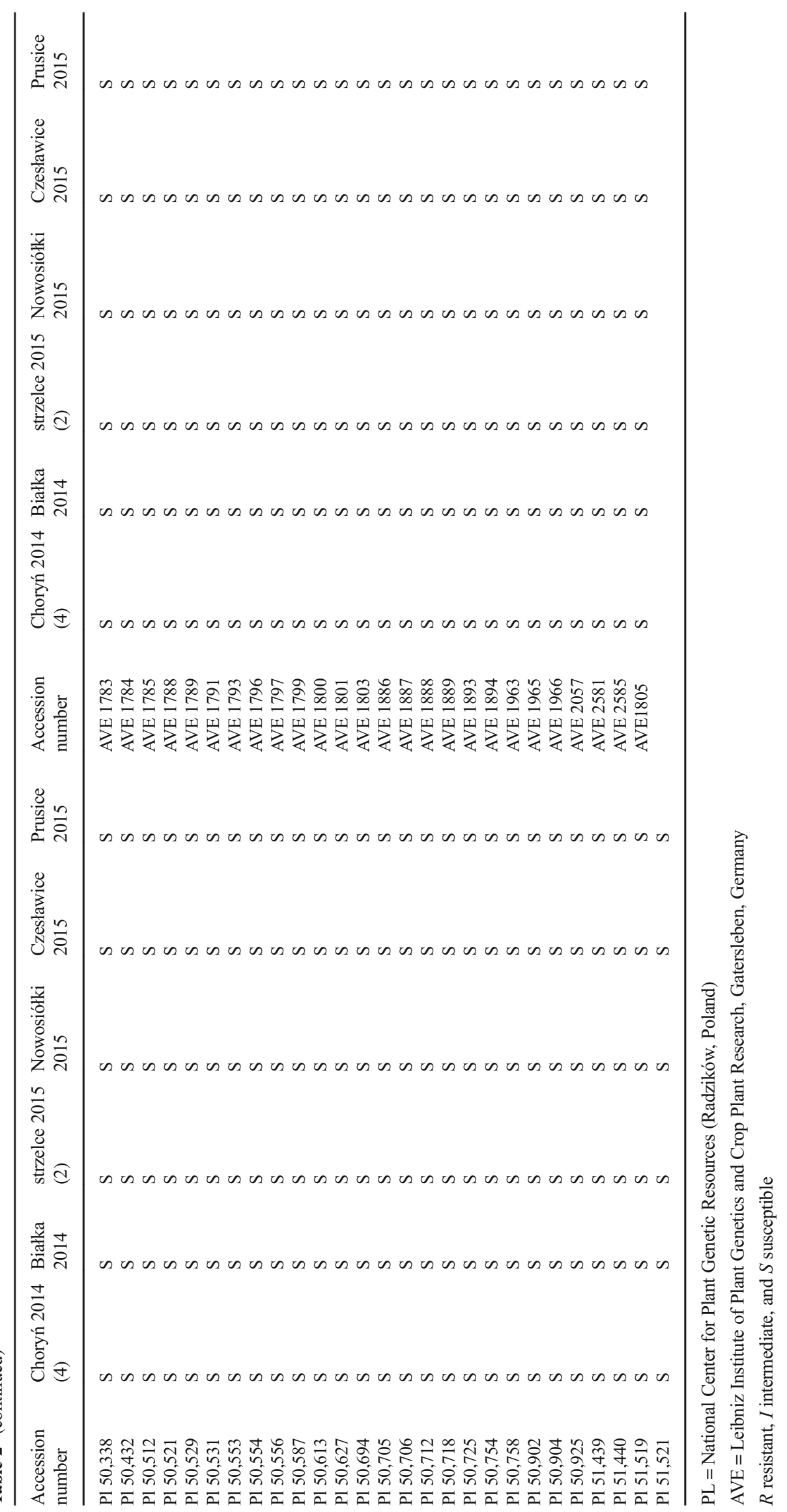


Table 3 Response of A.srigosa landraces to selected B. graminis f.sp. avenae isolates

\begin{tabular}{lllllll}
\hline Accession number & Choryń 2014 (4) & Białka 2014 & strzelce 2015 (2) & Nowosiółki 2015 & Czesławice 2015 & Prusice 2015 \\
\hline P1 51,586 & R & R & R & R & R & R \\
P1 51,585 & I & S & S & S & S & S \\
P1 51,630 & S & S & S & S & S & I \\
P1 51,754 & S & S & S & S & S & I \\
P1 51,613 & S & S & S & S & S & I \\
P1 501,048 & S & S & S & S & S & I \\
P1 51,518 & S & S & S & S & S & S \\
P1 51,523 & S & S & S & S & S & S \\
P1 51,524 & S & S & S & S & S & S \\
P1 51,520 & S & S & S & S & S & S \\
P1 51,751 & S & S & S & S & S & S \\
\hline
\end{tabular}

$\mathrm{PL}=$ National Center for Plant Genetic Resources (Radzików, Poland)

$R$ resistant, $I$ intermediate, and $S$ susceptible

presented study, all accessions were tested using six single spore isolates of B. graminis f.sp. avenae of divers geographic origin (Fig. 1). Their virulence was verified using a set of cultivars and lines with defined resistance genes (Table. 1).

In general, the tested genotypes showed a low level of resistance to oat powdery mildew. Among the A. sativa landraces, there were no completely resistant genotypes $(0-2$ in Mains scale). Among the 145 accessions, two (Ave 2663 and $51,634)$ were resistant to three among six tested isolates, three (Ave2813, 52,565 and 51,610) were resistant to two isolates and one genotype (51443), were resistant to single isolates. Thirty-nine of tested landraces belonging to A. sativa showed intermediate response to single isolates, but we did not identify any genotype which showed intermediate response to all tested isolates ( 3 in Mains scale). Most of them were susceptible to all tested B. graminis f. sp. avenae isolates (4 in Mains scale) (Table 2).

Among tested A. strigosa genotypes one (P1 51,586) showed resistant response to all six isolates used in hostpathogen tests. Five genotypes showed intermediate response to single isolates. The rest of them showed susceptible resopnce to B. graminis f. sp. avenae isolates used (Table 3).

Based on these tests we identify only one genotype fully resistant to $B$. graminis $\mathrm{f}$. sp. avenae isolates. The use of different isolates allows us to conclude that the identified source of resistance is highly effective in Polish condition. Also using isolates collected in two different years may indicate that the resistance identified in the $A$. strigosa genotype could be also effective over a longer period of time.

Open Access This article is licensed under a Creative Commons Attribution 4.0 International License, which permits use, sharing, adaptation, distribution and reproduction in any medium or format, as long as you give appropriate credit to the original author(s) and the source, provide a link to the Creative Commons licence, and indicate if changes were made. The images or other third party material in this article are included in the article's Creative Commons licence, unless indicated otherwise in a credit line to the material. If material is not included in the article's Creative Commons licence and your intended use is not permitted by statutory regulation or exceeds the permitted use, you will need to obtain permission directly from the copyright holder. To view a copy of this licence, visit http://creativecommons.org/licenses/by/4.0/.

\section{References}

Banyal DK, Sood VK, Singh A, Mawar R (2016) Integrated management of oat diseases in north-western Himalaya. Range Manag Agrofor $37: 84-88$

Bentley AR, Cromey MG, Farrokhi-Nejad R et al (2006) Fusarium crown and root rot pathogens associated with wheat and grass stem bases on the South Island of New Zealand. Australas Plant Pathol 35:495502. https://doi.org/10.1071/AP06053

Boczkowska M, Onyśk A (2016) Unused genetic resources: a case study of Polish common oat germplasm. Ann Appl Biol 169:155-165. https://doi.org/10.1111/aab.12289

Czembor HJ, Czembor JH (2001) Resistance to powdery mildew in barley cultivars and breeding lines included in 1998-2000 polish registration trials. Plant Breed Seed Sci 45:21-41

Figueroa M, Hammond-Kosack KE, Solomon PS (2018) A review of wheat diseases - a field perspective. Mol Plant Pathol 19:15231536. https://doi.org/10.1111/mpp.12618

Frankel OH, Brown AHD, Burdon JJ (1995) The conservation of plant biodiversity - Otto Herzberg Frankel, Anthony H. D. Brown, Jeremy James Burdon - Google Książki

Gacek ES (2000) Wykorzystanie różnorodności genetycznej roślin w zwalczaniu chorób roślin uprawnych. Post Nauk Rol 5:17-25

Herrmann MH, Mohler V (2018) Locating two novel genes for resistance to powdery mildew from Avena byzantinain the oat genome. Plant Breed 137:832-838. https://doi.org/10.1111/pbr.12655

Kuzdraliński A, Kot A, Szczerba H et al (2017) A review of conventional PCR assays for the detection of selected phytopathogens of wheat. J Mol Microbiol Biotechnol 27:175-189. https://doi.org/10.1159/ 000477544

Kuzdraliński A, Szczerba H, Kot A et al (2018) Development and application of a new PCR method for detection of Blumeria graminis $\mathrm{f}$. 
sp. tritici. J Mol Microbiol Biotechnol 28:137-146. https://doi.org/ $10.1159 / 000494432$

Li HB, Zhou MX, Liu CJ (2009) A major QTL conferring crown rot resistance in barley and its association with plant height. Theor Appl Genet 118:903-910. https://doi.org/10.1007/s00122-0080948-3

Mains EB (1934) Inheritance of resistance to powdery mildew, Erysiphe graminis tritici, in wheat. Phytopathology 24:1257-1261

Menardo F, Praz CR, Wyder S et al (2016) Hybridization of powdery mildew strains gives rise to pathogens on novel agricultural crop species. Nat Genet 48:201-205. https://doi.org/10.1038/ng.3485

Mohammadi R, Haghparast R, Sadeghzadeh B et al (2014) Adaptation patterns and yield stability of durum wheat landraces to highland cold rainfed areas of Iran. Crop Sci 54:944-954. https://doi.org/10. 2135/cropsci2013.05.0343

Moragues M, Zarco-Hernández J, Moralejo MA, Royo C (2006) Genetic diversity of glutenin protein subunits composition in Durum wheat landraces [Triticum turgidum ssp. turgidum Convar. durum (Desf.) MacKey] from the Mediterranean Basin. Genet Resour Crop Evol 53:993-1002. https://doi.org/10.1007/s10722-004-7367-3

Okoń SM (2015) Effectiveness of resistance genes to powdery mildew in oat. Crop Prot 74:48-50. https://doi.org/10.1016/j.cropro.2015.04. 004

Okoń S, Kowalczyk K (2012) Deriving isolates of powdery mildew (Blumeria graminis DC. f.sp. avenae Em. Marchal.) in common oat (Avena sativa L.) and using them to identify selected resistance genes. Acta Agrobot 65:155-160. https://doi.org/10.5586/aa.2012. 069

Okoń SM, Ociepa T (2017) Virulence structure of the Blumeria graminis DC.f. sp. avenae populations occurring in Poland across 2010 2013. Eur J Plant Pathol 1-8. https://doi.org/10.1007/s10658-017$1220-\mathrm{y}$

Okoń S, Ociepa T, Paczos-Grzęda E, Ladizinsky G (2018) Evaluation of resistance to Blumeria graminis (DC.) f. sp. avenae, in Avena murphyi and A. magna genotypes. Crop Prot 106:177-181. https://doi.org/10.1016/J.CROPRO.2017.12.025

Pecetti L, Doust MA, Calcagno L et al (2001) Variation of morphological and agronomical traits, andprotein composition in durum wheat germplasm from easternEurope. Genet Resour Crop Evol 48:609620. https://doi.org/10.1023/A:1013825821856

Pusadee T, Oupkaew P, Rerkasem B et al (2014) Natural and humanmediated selection in a landrace of Thai rice ( Oryza sativa). Ann Appl Biol 165:280-292. https://doi.org/10.1111/aab.12137
Reynolds M, Dreccer F, Trethowan R (2006) Drought-adaptive traits derived from wheat wild relatives and landraces. J Exp Bot 58: 177-186. https://doi.org/10.1093/jxb/erl250

Roderick HW, Jones ERL, Sebesta J (2000) Resistance to oat powdery mildew in Britain and Europe: a review. Ann Appl Biol 136:85-91

Saker M, Adawy S, Smith CM (2008) Entomological and genetic variation of cultivated barley ( Hordeum vulgare) from Egypt. Arch Phytopathol Plant Prot 41:526-536. https://doi.org/10.1080/ 03235400600881612

Sánchez-Martín J, Rubiales D, Prats E (2011) Resistance to powdery mildew (Blumeria graminisf.sp. avenae) in oat seedlings and adult plants. Plant Pathol 60:846-856. https://doi.org/10.1111/j.13653059.2011.02453.x

Sánchez-Martín J, Rubiales D, Sillero JC, Prats E (2012) Identification and characterization of sources of resistance in Avena sativa, A. byzantinaand A. strigosagermplasm against a pathotype of Puccinia coronataf.sp. avenaewith virulence against the Pc94 resistance gene. Plant Pathol 61:315-322. https://doi.org/10.1111/j. 1365-3059.2011.02514.x

Sebesta J, Kummer M, Roderick HW et al (1991) Breeding oats for resistance to rusts and powdery mildew in central Europe. Ochr Rostl 27:229-238

Teklu Y, Hammer K (2009) Diversity of Ethiopian tetraploid wheat germplasm: breeding opportunities for improving grain yield potential and quality traits. Plant Genet Resour 7:1-8. https://doi.org/10. 1017/S1479262108994223

Tratwal A, Rosiak A (2010) Fungal diseases occurrence in winter wheat pure stands and mixtures. Prog Plant Prot 50:963-968

Trethowan RM, Mujeeb-Kazi A (2008) Novel germplasm resources for improving environmental stress tolerance of hexaploid wheat. Crop Sci 48:1255. https://doi.org/10.2135/cropsci2007.08.0477

van Hintum TJL, Elings A (1991) Assessment of glutenin and phenotypic diversity of Syrian durum wheat landraces in relation to their geographical origin. Euphytica 55:209-215. https://doi.org/10.1007/ BF00021241

Villa TCC, Maxted N, Scholten M, Ford-Lloyd B (2005) Defining and identifying crop landraces. Plant Genet Resour 3:373-384. https:// doi.org/10.1079/PGR200591

Xue LH, Li CJ, Zhao GQ (2017) First Report of Powdery Mildew Caused by Blumeria graminison Avena sativain China. Plant Dis 101:1954. https://doi.org/10.1094/PDIS-05-17-0678-PDN

Publisher's note Springer Nature remains neutral with regard to jurisdictional claims in published maps and institutional affiliations. 